\title{
Modern Retail Impact on Store Preference and Traditional Retailers in West Java
}

\author{
Sandra Sunanto \\ Parahyangan Catholic University
}

\begin{abstract}
This study is distinctive in that it focuses on the impact of three types of modern retail. These are the mini market, the supermarket, and the hypermarket entrance in South East Asia. Introducing a store giving high diversity and choice in developing a country with large population into an environment of convenient one shop time saving stocking an extensive product range to create high consumer diversity. A survey was conducted using a questionnaire to investigate changes in consumers' store preferences as a result of the introduction of modern retail in West Java, and also to determine whether modern retail negatively influences sales the traditional retailers. This research focuses on retailers selling convenience goods and analyzes which attributes of modern retail practices creates an environment attracting consumers to shift their store preferences. The results will help both modern retailers and traditional retailers to understand this market better despite the potential controversy.
\end{abstract}

Keywords: retail, convenience goods, west java, store preference

\section{Introduction}

The presence of modern retail in Indonesia started with the emergence of supermarkets in 1970. Until 1983, supermarket formed a small sector located mainly in Jakarta area serving a niche of market-expatriates and upper-class Indonesians. Introduction of unimpeded aggressive market penetration of foreign modern retailers in Indonesia after 1998 was supported by government policies of trade globalization, particularly in the retail sector as it allowed foreign modern retailers to enter and to compete with local retailers. Before retail liberalization, foreign modern retailers entered the market through a franchise system.

After 1998, each foreign modern retailer had to initiate joint ventures with local retailers. However, foreign modern retailers were able to buy out local retailers due to their financial strength. An example for this is one of major local modern 
retailers, Hero, was acquired by Dairy Farm International (Hongkong) and later affected the acquisition of 22 TOPS supermarkets owned by the Royal Ahold Group, the Netherlands.

The existences of foreign modern retail in Indonesia has created controversies, especially after Carrefour and Giant entered the market in 1998 and 2002 due, in part to their negative impact on traditional markets and local suppliers. In June 2005, foreign retailers have gained $8.4 \%$ of the total market sales, that are dominated by convenience stores and hypermarkets.

Carrefour opened its first store in Jakarta in October 1998. At the end of 1999, Carrefour merged with Continent, and since then all of merged company stores operate under the Carrefour name. In early 2008, there are 41 stores located in 10 major cities in Indonesia, and expanded until in the first half year of 2011. Its philosophy comprises of competitive price, a complete merchandise assortment, and excellent services, has enabled Carrefour to achieve success in applying the concept of one-stop shopping, extremely low price, full range of assortment choices, selfservice, and free parking.

In April 2010, 40\% of Carrefour Indonesia's shares were purchased by a national Group, Para Group. The new shareholder composition shows that majority of Carrefour Indonesia's shares is owned by the national entrepreneur who focuses on building a good synergy among Carrefour, farmers or suppliers, and traditional retailers.

Hero supermarket was the first supermarket introduced in Indonesia in 1971 by M. Saleh Kurnia. Today, Hero is a retail group which offers four formats - Hero (supermarket), Giant (hypermarket), Guardian (drugstore), Starmart and Mitra (convenience). At the end of 2009, Hero was operating 35 Giant hypermarkets, 50 Hero supermarkets, 63 Giant supermarkets, 195 Guardians, and 124 Star Marts. Hero also has expanded into other countries including Malaysia, Brunei, and China.

In 2010, a giant Hongkong retail group, Dairy Farm, officially owns $94.27 \%$ of Hero's stocks through its subsidiary, Mulgrave Corporation BV. The presence of Giant hypermarket in Indonesia is a part of Dairy Farm strategy as the owner to expand Giant market into the Southeast Asia and the Middle East.

Other major players are Hypermart and Lotte Mart. The presence of Hypermart in Indonesia cannot be separated from the biggest retail group in this country, PT. Matahari Putra Prima, Tbk (Matahari). Hypermart representing the modern, compact style hypermarket business within the fast growing Indonesia FMCG market with its nationwide operation through its current 47 stores spread over 21 cities and it will continue to expand in major areas in Indonesia.

Matahari also provides supermarket format for its customers, namely Foodmart, that represents the latest incarnations of the modern supermarket for lifestyle grocery shopping and convenience. 
In September 2008, Lotte group from Korea acquired Makro Indonesia by buying all its shares from the Netherlands SHV Holding NV. All Makro stores in Indonesia changed the store brand to Lotte Mart and plan to open 26 more stores to compete in the Indonesian retail market.

After 2000, mini market format has aggresively expanded its stores with two major local players - Alfamart, and Indomaret. Alfamart was established on June $27^{\text {th }}$, 1999, and currently, this mini market owns around 3,000 stores and has experienced dramatic growth using the franchise system. Indomaret is mini market chain store that provides convenience goods with an average sales area of less than $200 \mathrm{~m}^{2}$. Indomaret owned 4,110 stores in March 2010, of which 2,327 of them are owned by Indomaret while the rest of them are owned by franchisees in some cities.

\section{Background Information}

The province of West java is the densest area in Indonesia exceeding 43 million inhabitants dispersed across 26 districts. Bandung is the capital city of this province has the biggest population with 7,083,700 people located in this area, followed by Bogor $(5,722,266)$, and Bekasi $(4,965,272)$ (Sensus Penduduk, Badan Pusat Statistik, 2010).

Bandung as the capital city of West Java is the backbone of this province's economy through the existences of several sectors of high potential i.e. tourism, manufacturing, and large scale retail. One of the fastest growing sectors in this city is modern retail. There were 17 department stores, 5 hypermarkets, 40 supermarkets, and 60 mini markets in 2007 (Kementerian Perdagangan Republik Indonesia 2010) compared to only 75 of traditional retailers in the same year. Unfortunately, the number of traditional retailers, particularly the traditional market has been continuously decreasing since rapid development of modern retail. To create a healthy business environment, the government has issued a trade regulation in 2009, which consists of some important concepts such as fair trade, zoning regulation, and partnership between modern retailers and local merchants.

As the buffer city of Jakarta, Depok has experienced an intensive growth of modern retail. There were nine traditional markets surrounded by 62 modern retailers in 2006, and 46 of them were mini markets while there were also three new supermarkets beginning operation. As modern retailers exist in this area, traditional supermarket and also traditional stores has been replaced by new supermarkets and other types of modern retail. This municipality has its own rules for regulating markets including modern markets, however, there is nothing in these regulations to address some important issues including rights and obligations of merchants, zoning regulations and, partnerships between modern retailers and local producers.

However, the development of modern retail has been posed a big question as to whether modern retailers negatively influence traditional retailers. Previous studies found that most of traditional retailers have had difficulties competing with the modern retailer which has resulted in reducing traditional stores share of sales and profit (Hernandez, 2003; Peterson and McGee, 2000, Seiders and Tigert, 2000; 
Farhangmehr et al., 2000; Arnold and Luthra, 2000; Vance and Scott, 1994). But, there was an interesting finding from a study of traditional market versus supermarket in Hongkong, in that consumers perceived wet markets and supermarkets as complementing one another and as being equally important (Goldman, Krider and Ramaswami, 1999).

Indonesia defines traditional retailers as merchants who sell their merchandise in a small store owned by them or rent a space located in a traditional market or near a traditional market and/or residential area. They own and operate their business by themselves with 2-5 employees and usually involve their family members. However, there is one type of traditional retailer who sells merchandises openly on the pedestrian area namely street hawker. There are some types of traditional retailer known in this country: 1). traditional (wet) market, 2). small kiosk, called warung, 3). mom and pop store, and 4). street hawker. The traditional market is perceived as an old building, wet and dirty, and unsafe hence creates an inconvenient shopping environment due to bad management. It is supported by the fact that $67 \%$ of current traditional markets were built between 1976 and 1979 and most of them have never been renovated (Kementerian Perdagangan Republik Indonesia 2010).

The role of traditional markets in providing goods needed by consumers is very important, which is shown from the major variety of goods offered in traditional markets. Most of goods sold in traditional markets are staple goods such as rice, flour, sugar, fish, eggs, and cooking oil (57.8\%), foods and beverages (20\%), groceries (16\%), clothes and shoes (12.22\%), and other goods such as building materials, medicines, electronic goods (10\%) (Kementerian Perdagangan Republik Indonesia 2010).

The development of modern market provides more choices for consumers to decide where they can do shopping. Consumers start to prefer to buy groceries in hypermarket or supermarket compare to the traditional market because of cleanliness, and conveniences. However, a previous study found that traditional market still became the most favorite place for shopping fresh goods markets (Goldman, et al., 1999), and particulary, modern market entry in West Java did not significantly influence the business performance of traditional markets (Suryadarma, et al., 2007).

With regard to Suryadarma et al. study that focused only on the impacts of supermarket and hypermarket in two major cities in West Java on traditional markets, and considering ongoing debates on modern retail development, this study tries to provide more thorough analysis by including not only supermarket, hypermarket, and traditional market, but also mini market, and other traditional retailers as the unit analysis.

The objectives of this study are:

(1) to investigate the effect of mini market, supermarket, and hypermarket existence on consumers' store preferences for the purchase of grocery goods;

(2) to discover which store attributes of modern retailers influence consumers to shift their preferences from traditional retailers to modern retailers;

(3) to analyze the impact of modern retailers on the traditional retailers i.e. traditional market, small kiosk, traditional grocery store, and street hawker. 


\section{Theoretical Review}

\section{Modern retail and consumer store preference}

Literature on retailing shows that there are several reasons for customer switching behavior: convenient location, changes in pricing, range of assortment, comfort services, quality, store environment, competition, ethical problems, and involuntary switching (Seiders and Tigert, 2000; Arnold, et al., 1983; Louviere and Garth, 1987; Eagle, 1984). Switching cost plays an important role in a customer's decision to change. A new entrant who has a greater competitive advantage by bringing noticeable distinction with lower switching costs acquires a bigger portion of the switcher segment (Seiders and Tigert, 2000).

A study of consumer perceptions on the hypermarket and traditional stores in Portugal showed that consumers prefer to buy convenience goods or low involvement goods from the hypermarkets because they offer more benefits regarding prices, promotions, assortment, novelties, and schedules (Farhangmehr, et al., 2000). However, for high involvement goods such as household appliances, consumers prefer to buy those goods from traditional retail stores considering the benefit of saving time spent on shopping. Farhangmehr, et al,. (2000) study finds that there is no loyalty to a single retail format, that proves that consumers prefer to buy in hypermarket; they also buy in several outlets and not exclusively in the hypermarket.

Modern retailer strategies take advantage of consumer ambiguity to shift consumer preferences in its favor. In another words, modern retailers may influence or even change consumer preferences (Seiders and Tigert, 2000). By modeling price and cost structures of grocery retailers, Setala (2000) found that modern large grocery retailers achieved store level economies, where both costs and prices were lower than small stores, and consumers enjoyed this benefit. Location, transportation cost, and household size determine the consumer's utility; these large households are the ones that gain the main benefit from modern large retailers. However, the situation may not be the same in other local markets.

As consumers are asked to compare small stores versus big stores, they display interesting perceptions of both types. Uusitalo (2001) study found that consumers perceive a small store is attractive because shopping there is efficient, fast, and simple. Accessibility, familiarity, and intimacy are important factors, which encourage consumers to shop in small stores. Big stores, which are usually located in city centre, are associated with a wide variety of goods, encompassing a lot of walking and searching, and buying more goods at a lower price. Some consumers feel that shopping in big stores is convenient, however they compensate their extra walking in a big store space by its one stop shopping concept. An interesting experience through service and merchandise become a major consideration that causes consumers to show willingness to accept extra travel efforts to buy grocery and fresh goods (Sinha and Banerjee, 2004). However, their research in the Indian retailing sector found that the most important factor in attracting consumer loyalty for grocery stores was proximity, not the store atmosphere. 
There are some interesting findings regarding consumer's perception of traditional and modern retailers. A study of the traditional market versus the supermarket in Hongkong found that consumers perceived wet markets and supermarkets as complementing one another and both being equally important (Goldman, Krider and Ramaswami, 1999). While wet markets offered more advantages than supermarkets in fresh food, consumers complained about the store/market environment, which did not have adequate convenience to do their shopping comfortably. Even though large modern retailers with mass merchandise sell the same products as traditional grocers, there is no direct substitution relationship between traditional grocery retailers and mass merchandisers (Fox, Montgomery, and Lodish, 1994).

A study of consumers preferences on small retailers in Latin America (D'Andrea and Lopez, 2006) shows that consumers do not prefer to buy in supermarkets or hypermarkets for a number of reasons. First, they need to spend extra time and money for transportation as they must travel comparatively further to get to those stores. The second reason is that consumers do not like how the staff of large retailers treats them. Finally, consumers perceive small retailers are cheaper than the large ones. However, customer perceptions of indirectly competing stores differ between primary and secondary store loyaly (Mitchell and Kiral, 1998).

Recent studies on the impact of modern retailers on store preferences in West Java, Indonesia (Sunanto and Tuninga, 2009; Sunanto, et al., 2010) found that the opportunity to bargain and indulge in personal relationships between sellers and buyers are the main reasons why people still prefer to buy goods at a traditional market rather than at a modern market (Sunanto and Tuninga, 2009). Consumers switched their buying preferences from traditional stores to modern retailers, particularly supermarket due to convenience, assortment, and cleanliness. The one stop shopping concept becomes a competitive advantage offered by modern retailers to attract consumers to switch their buying preferences from traditional markets to modern retailers (Sunanto, et al.2010).

With regards to previous studies, this study proposes hypotheses which elaborate consumer's store preference for buying goods in grocery category after entry of modern retailers:

H1: Consumers have shifted their store preferences for fresh goods after the entry of modern retailers;

H2: Consumers have shifted their store preferences for staple goods after the entry of modern retailers;

H3: Consumers have shifted their store preferences for foods and beverages after the entry of modern retailers;

H4: Consumers have shifted their store preferences for toiletries and other goods after the entry of modern retailers.

\section{Modern retail and indigenous traditional retailers}

A previous study on large retailer impact on the performance of existing retailers showed that there was such rapid market penetration in the initial growth stage, that is caused a decline in the sales of local retail stores, and growth and decline in various 
commercial sectors caused by large retailer entry (Arnold and Luthra, 2000). Where the large retailers penetrate markets aggressively, indigenous retailers experience a decline in sales, market share, and profits. Research on Wal-Mart entry in the East Coast region of the US shows that local supermarkets lost $17 \%$ in sales volume amounting to a quarter million dollars of monthly revenue following Wal-Mart's entry (Singh, Hansen, and Blattberg, 2004).

Study on hypermarkets entry in Malaysia shows that traditional outlets such as independent grocers and mini markets gradually closed. Emergence of modern retailing such as supermarket and hypermarket filled this gap (Shamsudin and Selamat, 2005). Local traditional retailers face intense competition from foreign hypermarkets and try hard to maintain their customers; however, they experience declining sales with low turnover.

Most of local and traditional retailers face difficulties in competing with large format retailers as indicated by a declining market share, sales, and profit (Hernandez, 2003; Peterson and McGee, 2000, Seiders and Tigert, 2000; Farhangmehr, et al.,, 2000; Arnold and Luthra, 2000; Vance and Scott, 1994). This phenomenon does not only happen in the host market, but also in the neighboring markets. The impact of large format retailer entry such as Wal-Mart may change not only the total sales, but also the distribution of sales through the various types of retail categories in the host community where Wal-Mart exists (Davidson and Rummel, 2000; Stone, 1995).

Stone's study (1995) finds that all retail categories except food or grocery stores in the non- Wal-Mart towns were negatively affected after five years of Wal-Mart's entry. There are two rules of thumbs recommended by Stone:

1. Merchants selling items that differ from those sold by the large format retailers will probably not experience a loss of sales. In fact, if these stores are in close proximity to the discount stores, they experience an increase in sales after the discount store opens because they benefit from the "spillover" of the additional traffic generated by the discounter.

2. Merchants selling the same things that the large format retailers are selling will probably experience a decrease in sales after the discounter opens. This applies not only to merchants in the local area, but those in the neighboring areas.

Davidson and Rummel study (2000) also find that Wal-Mart neighboring towns experienced a decline or only small increases in retail trade during the same period with the Wal-Mart host towns. Other research supported the facts that the entry of large format retailer stimulates growth in certain retail categories, but leads to a decline in other categories (Arnold and Luthra, 2000, Stone, 1995). Based on those previous studies, this study proposes a hypothesis:

H5: modern retailers negatively influence sales of traditional retailers

\section{Methodology}

This study performed a survey conducted in three major cities in West Java Bandung, Bogor and Depok considering that in those cities we can find supermarkets, hypermarkets, and also mini markets that were established during 
2003-2007. There were two groups of respondents in this survey - consumers who have had experiences shopping at modern retailers and traditional retailers who operated their businesses at least two years before the entry of modern retailers in their areas.

Questionnaires were delivered to 550 consumers and 300 traditional retailers. Consumers were asked to give information of their store preferences before and after the entry of modern retailers, and their perceptions on store attributes of modern retailers, while traditional retailers were asked to report their businesses performance in terms of relative sales number after the entry of modern retailers in their areas.

\section{Measures}

A preliminary questionnaire for the consumers' survey was compiled by focus group discussions, and from three previous studies in Moreno (2001), Farhangmehr et al., (2000), and Carpenter and Moore (2006), that was tested by 100 respondents. A cluster sampling method was used to select the samples from people who live in the area near both modern markets and traditional markets $(0-3 \mathrm{~km})$. A respondent should have an experience with grocery shopping both in one of modern retailers and in one of traditional retailers in the last six month. Mc Nemar's test for two related samples from a categorical field was used to analyze whether consumers shift their store preferences from traditional retailers to modern retailers after an entry of modern retailers in their neighborhoods.

To test consumers' perceptions on store attributes, they were asked to choose three provided responses, whether modern retailers provided worse, same, or better attributes compared to traditional retailers. The Spearman Rank's correlation was conducted to test consumers' perceptions on store attributes of modern retailers, which influenced their preferences to shop at modern retailers.The correlation coefficient is able to indicate which store attributes have strong, moderate, or weak influences on consumers preferences on modern retailers.

Using the same sampling method with consumer survey, a retailer survey measured the effect of modern retail entry on traditional retailers' sales, whether their sales decreased, increased or did not experience any changes. Using Chi-square test, this study was used to test the hypothesis whether the entry of modern retailers influenced sales of traditional retailers.

Results of Cronbach's Alpha test for consumer and retailer survey respectively are 0.601 and 0.590 shows that all questions asked in both questionnaires are reliable enough to support this study. 


\section{Findings and Discussions}

\section{Consumer store preference and store attributes}

There are some anomalies in patterns of consumers shopping frequency (Table 1). Consumers usually go to small kiosk near their house to buy goods related to daily needs such as vegetables, seasoning, snacks, and toiletries while mosst consumers prefer to do shopping at traditional market for fresh goods that are purchased on a weekly basis due the location of traditional markets that are further from their houses. Another option for obtaining fresh goods is the frequent availability of street hawkers that usually offer their merchandises door to door of some neighborhoods. Consumers found that they spent less time and efforts buying from street hawkers compare to the traditional markets or other retailers.

Shopping at supermarkets and hypermarkets is mostly preferred on monthly schedule and the majority of goods bought at the modern retailers are foods and beverages, toiletries, and household goods. Contrary to this, consumers also prefer to buy fruit at supermarket and/or hypermarket due to the fresh quality and cheaper prices. It is common for consumers go to mini market for a "fill-in" trip; consequently they do not spend much time or money at the mini market.

Table 1 Shopping frequency (\%)

\begin{tabular}{|l|c|c|c|c|c|c|}
\hline & \multicolumn{6}{|c|}{ Shopping Frequency } \\
\hline & Daily & Weekly & Monthly & Quarterly & Semester & Total \\
\hline $\begin{array}{l}\text { Traditional } \\
\text { market }\end{array}$ & 35.6 & 50.7 & 12.5 & 1.2 & 0 & 100 \\
\hline $\begin{array}{l}\text { Street } \\
\text { hawker }\end{array}$ & 34.6 & 39.3 & 14.0 & 12.1 & 0 & 100 \\
\hline Kiosk & 75.6 & 17.8 & 4.0 & 2.6 & 0 & 100 \\
\hline Mini market & 2.0 & 39.4 & 39.8 & 18.9 & 0 & 100 \\
\hline Supermarket & 0.3 & 21.1 & 74.2 & 2.8 & 1.5 & 100 \\
\hline Hypermarket & 0 & 5.2 & 63.5 & 30.7 & 0.5 & 100 \\
\hline
\end{tabular}

There were four product categories analyzed in this study to show whether consumers changed their store preferences after the entry of modern retailers. McNemar's test shows that consumers have changed their store preferences from traditional retailers to modern retailers for all products in the first category, fresh goods especially fruits (Table 2). Consumers also preferred to buy staple goods, particularly sugar and salt, egg, and cooking oil and butter at modern retailers (Table 3). 
Table 2 McNemar's test for fresh goods

\begin{tabular}{|l|r|r|r|r|r|}
\hline & Meats & Vegetables & Fruits & \multicolumn{1}{c|}{ Fish } & \multicolumn{2}{c|}{$\begin{array}{c}\text { Raw } \\
\text { seasoning }\end{array}$} \\
\hline $\mathrm{N}$ & 520 & 539 & 532 & 530 & 537 \\
\hline $\begin{array}{l}\text { Shift of shopping place } \\
(\%)\end{array}$ & 24.2 & 22.3 & 49.1 & 20.4 & 18.2 \\
\hline Chi-Square $^{\mathrm{a}}$ & 121.071 & 118.008 & 259.004 & 106.009 & 96.010 \\
\hline Asymp. Sig. $^{\text {A }}$ & .000 & .000 & .000 & .000 & .000 \\
\hline
\end{tabular}
a. Continuity Corrected
b. McNemar Test

Table 3 McNemar's test for staple goods

\begin{tabular}{|c|c|c|c|c|}
\hline & Rice & $\begin{array}{l}\text { Sugar and } \\
\text { Salt }\end{array}$ & Egg & $\begin{array}{l}\text { Cooking oil and } \\
\text { Butter }\end{array}$ \\
\hline $\mathrm{N}$ & 535 & 535 & 536 & 538 \\
\hline $\begin{array}{l}\text { Shift of shopping place } \\
\text { (\%) }\end{array}$ & 20.9 & 46.4 & 44.0 & 62.5 \\
\hline Chi-Square $^{\mathrm{a}}$ & 110.009 & 246.004 & 234.004 & 331.027 \\
\hline Asymp. Sig. & .000 & .000 & .000 & .000 \\
\hline
\end{tabular}

a. Continuity Corrected

b. McNemar Test

Modern retailers provide a high variety of food and beverages as well as toiletries, which are attractively displayed giving greater choice of comparative brands on the shelves, therefore consumers prefer to buy those goods at modern retailers (Table 4 and Table 5).

Table 4 McNemar's test for foods and beverages

\begin{tabular}{|c|c|c|c|c|c|c|c|c|c|}
\hline & $\begin{array}{c}\text { Milk, } \\
\text { Coffee } \\
\text { and Tea }\end{array}$ & Softdrinks & Snacks & Bread & Cake & $\begin{array}{c}\text { Mineral } \\
\text { water }\end{array}$ & $\begin{array}{c}\text { Canned } \\
\text { foods }\end{array}$ & Confectionnaries & $\begin{array}{l}\text { Instant } \\
\text { noodle }\end{array}$ \\
\hline $\mathrm{N}$ & 538 & 482 & 517 & 524 & 503 & 334 & 367 & 457 & 531 \\
\hline $\begin{array}{l}\text { Shift of } \\
\text { shoppin } \\
\text { g place } \\
(\%)\end{array}$ & 67.5 & 64.9 & 62.1 & 49.2 & 45.9 & 35 & 81.7 & 64.6 & 65.7 \\
\hline $\begin{array}{l}\text { Chi- } \\
\text { Square }^{a}\end{array}$ & 361.003 & 311.003 & 319.003 & 256.004 & 229.004 & 115.009 & 298.003 & 293.003 & 347.003 \\
\hline $\begin{array}{l}\text { Asymp. } \\
\text { Sig. }\end{array}$ & .000 & .000 & .000 & .000 & .000 & .000 & .000 & .000 & .000 \\
\hline
\end{tabular}

a. Continuity

Corrected

b. McNemar Test 
Table 5 McNemar's test for toiletries and other goods

\begin{tabular}{|l|r|r|r|}
\hline & Toiletries & Body treatment & Detergent \\
\hline $\mathrm{N}$ & 538 & 514 & 535 \\
\hline Shift of shopping place (\%) & 84 & 86 & 75.5 \\
\hline Chi-Square $^{\mathrm{a}}$ & 450.002 & 440.002 & 402.002 \\
\hline Asymp. Sig. & .000 & .000 & .000 \\
\hline
\end{tabular}

a. Continuity Corrected

b. McNemar Test

All McNemar' test for four product categories have accepted four hypotheses (H1H4), which means that consumers prefer to buy fresh goods, staple goods, food and beverages, and toiletries and other goods at modern retailers, compare to buy those goods at traditional retailers.

Using spearman rank's correlation, this study found that consumers have changed their preferences due to the attributes offered by modern retailers (Table 6). The most preferred attributes were product availability, product quality, and product prices. Store location and promotion were not enough to attract consumers to shop at modern retailers (Table 7).

Table 6 Spearman's rank correlation of consumers' perceptions on modern retailers' stores attributes and store preferences

\begin{tabular}{|l|l|l|r|r|}
\hline \multicolumn{2}{|c|}{} & \multicolumn{1}{c|}{$\begin{array}{c}\text { Consumer } \\
\text { perception on } \\
\text { total attributes }\end{array}$} & \multicolumn{1}{c|}{$\begin{array}{c}\text { Consumer } \\
\text { store } \\
\text { preference }\end{array}$} \\
\hline \multirow{2}{*}{$\begin{array}{l}\text { Spearman's } \\
\text { rho }\end{array}$} & $\begin{array}{l}\text { Consumer } \\
\text { perception on total } \\
\text { attributes }\end{array}$ & $\begin{array}{l}\text { Correlation } \\
\text { Coefficient }\end{array}$ & 1.000 & $.535^{* *}$ \\
\cline { 3 - 5 } & Sig. (1-tailed) & & .000 \\
\cline { 2 - 5 } & N & 551 & 551 \\
\cline { 2 - 5 } & $\begin{array}{l}\text { Consumer store } \\
\text { preferences }\end{array}$ & $\begin{array}{l}\text { Correlation } \\
\text { Coefficient }\end{array}$ & $.535^{* *}$ & 1.000 \\
\cline { 3 - 5 } & Sig. (1-tailed) & .000 & 551 \\
\cline { 3 - 5 } & $\mathrm{N}$ & 551 & \\
\hline
\end{tabular}

**. Correlation is significant at the 0.01 level (1tailed). 
Table 7 Spearman rank's correlation of each modern retailers' stores attributes

\begin{tabular}{|l|r|r|}
\hline \multicolumn{1}{|c|}{ Attributes } & Correlation coefficient & Sig. (1-tailed)* \\
\hline Product availability & .405 & .000 \\
\hline Product quality & .375 & .000 \\
\hline Product price & .359 & .000 \\
\hline Shopping cost & .358 & .000 \\
\hline Product assortment & .317 & .000 \\
\hline Payment method & .315 & .000 \\
\hline Store location & .273 & .000 \\
\hline Store area & .247 & .000 \\
\hline Promotion & .091 & .017 \\
\hline
\end{tabular}

\section{Traditional retailers’ performances}

The impact of modern retailers on traditional retailers is measured by decreases or increases in their number of sales after the entry of modern retailers. Mini markets did not significantly influence all traditional retailers, but had a slightly negative impact on sales of traditional market and kiosks (Table 8). Sales of toiletries, food and beverages were the most influenced by mini markets.

Table 8 Sales changes due to mini market entry

\begin{tabular}{|l|c|c|c|c|c|c|}
\hline & \multicolumn{5}{|c|}{ Sales } \\
\hline & \multicolumn{2}{|c|}{ Decrease } & No change & \multicolumn{2}{c|}{ Increase } & \\
\hline & $\begin{array}{c}\text { More } \\
\text { than 50\% }\end{array}$ & $\begin{array}{c}\text { Less than } \\
50 \%\end{array}$ & & $\begin{array}{c}\text { Less than } \\
50 \%\end{array}$ & $\begin{array}{c}\text { More } \\
\text { than } 50 \%\end{array}$ & Total \\
\hline $\begin{array}{l}\text { Traditional } \\
\text { market }\end{array}$ & 2.5 & 15.6 & 51.6 & 0 & 0.8 & 70.5 \\
\hline Kiosk & 9 & 6.5 & 7.4 & 0 & 0 & 22.9 \\
\hline $\begin{array}{l}\text { Street } \\
\text { hawker }\end{array}$ & 0 & 2.5 & 4.1 & 0 & 0 & 6.6 \\
\hline Total & 11.5 & 24.6 & 63.1 & 0 & 0.8 & 100 \\
\hline
\end{tabular}

Similar patterns were also evident when supermarkets appeared in close proximity to traditional retailers (Table 9). Traditional markets faced larger sales reductions than other traditional retailers due to the shift of consumer preferences for supermarkets with fresh goods, food and beverages, and toiletries. 
Table 9 Sales changes due to supermarket entry

\begin{tabular}{|l|c|c|c|c|c|c|}
\hline & \multicolumn{7}{|c|}{ Sales } \\
\hline & \multicolumn{2}{|c|}{ Decrease } & No change & \multicolumn{2}{c|}{ Increase } & Total \\
& $\begin{array}{c}\text { More } \\
\text { than 50\% }\end{array}$ & $\begin{array}{c}\text { Less than } \\
50 \%\end{array}$ & & $\begin{array}{c}\text { Less than } \\
50 \%\end{array}$ & $\begin{array}{c}\text { More } \\
\text { than 50\% }\end{array}$ & (2.5 \\
\hline $\begin{array}{l}\text { Traditional } \\
\text { market }\end{array}$ & 2.4 & 25.8 & 30.5 & 1.0 & 0 & 59.7 \\
\hline Kiosk & 2.4 & 12.7 & 18.3 & 2.0 & 0 & 35.4 \\
\hline $\begin{array}{l}\text { Convenience } \\
\text { store }\end{array}$ & 0 & 0.5 & 0.5 & 0 & 0 & 1.0 \\
\hline $\begin{array}{l}\text { Street } \\
\text { hawker }\end{array}$ & 0 & 0.5 & 1.5 & 1.9 & 0 & 3.9 \\
\hline Total & 4.8 & 39.5 & 50.8 & 4.9 & 0 & 100 \\
\hline
\end{tabular}

Although hypermarkets offer a large selection of goods and a different store atmosphere, the majority of traditional retailers found no significant sales reductions following the entry of hypermarkets, the exception being for some merchants selling similar goods in traditional markets experienced a sales decrease (Table 10).

Table 10 Sales changes due to hypermarket entry

\begin{tabular}{|l|c|c|c|c|c|c|}
\hline & \multicolumn{7}{|c|}{ Sales } \\
\hline & \multicolumn{2}{|c|}{ Decrease } & No change & \multicolumn{2}{c|}{ Increase } & Total \\
& $\begin{array}{c}\text { More } \\
\text { than 50\% }\end{array}$ & $\begin{array}{c}\text { Less than } \\
50 \%\end{array}$ & & $\begin{array}{c}\text { Less than } \\
50 \%\end{array}$ & $\begin{array}{c}\text { More } \\
\text { than 50\% }\end{array}$ & T. \\
\hline $\begin{array}{l}\text { Traditional } \\
\text { market }\end{array}$ & 2.5 & 22.8 & 34.7 & 0.4 & 0.4 & 60.8 \\
\hline Kiosk & 0.4 & 11.0 & 13.6 & 0.7 & 0.4 & 26 \\
\hline $\begin{array}{l}\text { Convenience } \\
\text { store }\end{array}$ & 0.8 & 4.0 & 4.8 & 0 & 0 & 9.6 \\
\hline $\begin{array}{l}\text { Street } \\
\text { hawker }\end{array}$ & 0 & 0.7 & 2.9 & 0 & 0 & 3.6 \\
\hline Total & 3.7 & 38.5 & 56 & 1.0 & 0.8 & 100 \\
\hline
\end{tabular}

Using Chi-Square test for one sample with 95\% level of confidence, this study supports the hypothesis that mini markets, supermarkets, and hypermarkets entry negatively influenced the traditional retailers' sales (Table 11).

Table 11 Hypothesis Testing

\begin{tabular}{|c|c|}
\hline Null Hypothesis & Sig. \\
\hline $\begin{array}{l}\text { 1. The categories of sales after mini market entry occur with equal } \\
\text { probabilities }\end{array}$ & .000 \\
\hline $\begin{array}{l}\text { 2. The categories of sales after supermarket entry occur with equal } \\
\text { probabilities }\end{array}$ & .000 \\
\hline $\begin{array}{l}\text { 3. The categories of sales after hypermarket entry occur with equal } \\
\text { probabilities }\end{array}$ & .000 \\
\hline
\end{tabular}




\section{Conclusion}

This study examined the effects of modern retailers in changes of consumers store preferences and also comparative sales trends of traditional retailers. The results of this study show that consumers have shifted their store preferences to modern retailers for all product categories studied due to product availability with good quality, prices, and assortment. The numbers of traditional markets have been noticeably reduced in some cities, this study's findings support the hypothesis that modern retailers negatively influence sales in this type of market.

This study has a limitation by using categorical data to investigate the shift of store preferences and to examine sales trends of traditional retailers after modern retailers' entries. Future research will be encouraged to explore the impacts of modern retail development on other important issues such as local economy and environment. A comparative study between two countries with different characteristics is also an interesting option to be explored.

\section{Theoretical Implications}

This study provides both theoretical and managerial contributions to the areas of retailing and consumer behavior. In terms of theoretical implications, the results of current study proposes that product availability and product quality are two main reasons why consumers shift their preferences from traditional retailers to modern retailers, thus, not in line with previous studies, which found that price was the main reason (Farhangmehr, et al., 2000; Setala, 2000).

The study results contribute to the retail development and consumer behavior literature by suggesting major retail atrributes that significantly influence store preferences. The retail development has to consider its impacts on indigenous retailers, particularly traditional retailers, although only traditional markets have been experiencing significant impact on sales. Further research may examine the impact of retail development on backward and forward linkage of retail value chain.

\section{Managerial Implications}

The findings of this study might have at least some important business implications. Managers of modern retail and merchants of traditional retailers could understand how to attract consumers by offering more selective store attributes to individualize themselves. Considering the pros and cons of modern retailers, particularly in Indonesia, this study presents findings that could be useful for traditional retailers to identify areas of opportunity in the face of strong competition from modern retailers.

It is acknowledged that government plays an important role in developing the competitiveness of traditional retailers; however, government must also manage the development of modern retailers in order to provide win-win solutions for all stakeholders. Regulations of these retail markets needs to be monitored carefully due to the gap of autonomy in common practice. 


\section{Acknowledgement}

We wish to express our gratitude to the Indonesia General Directory of Higher Education (Ditjen Dikti) for providing the financial means through the program of Competitive Research Grant (Hibah Penelitian Bersaing).

\section{References}

Arnold, S.J. and Luthra, M.L. (2000), "Market Entry Effects of Large Format Retailers: A Stakeholder Analysis", International Journal of Retail and Distribution Management, vol. 48, no. 4/5.

Arnold, S. J., Tae, O.H. and Tigert, D.J. (1983), "Determinant Attributes in Retail Patronage: Seasonal, Temporal, Regional, and International Comparisons", Journal of Marketing Research, vol. 20, pp. 149-157.

Asian Wall Street Journal, 30 November 1998.

Carpenter, J.M. and Moore, M. (2006). "Consumer Demographics, Store Attributes, and Retail Format Choice in the US Grocery Market”, International Journal of Retail and Distribution Management, vol. 34, no. 6, pp. 434-452.

Davidson, S.M. and Rummel, A. (2000), "Retail Changes Associated with Wal-Mart's entry into Maine”, International Journal of Retail \& Distribution Management, vol. 28, no. 4/5, pp. 162-169.

D’Andrea, G. and Lopez, A. (2006), "Why Small Retailers Endure in Latin America”, International Journal of Retail \& Distribution Management, vol. 34, no. 9, pp.661673.

Eagle, T. (1984), "Parameter Stability in Disaggregate Retail Choice Models: Experimental Evidence”, Journal of Retailing, vol. 60, no.1, pp. 101-23.

Farhangmehr, M., Marques, S. and Silva, J.(2000), “Consumer and Retailer Perceptions of Hypermarkets and Traditional Retail Stores in Portugal”, Journal of Retailing and Consumer Services, vol. 7, pp. 197-206.

Fox, E.J., Montgomery, A.L. and Lodish, L.M. (1994). "Consumer Shopping and Spending Across Retail Formats”, Journal of Business, vol. 77, no. 2, pp. 825-860.

Goldman, A., Krider, R. and Ramaswami, S. (1999).” The Persistent Competitive Advantage of Traditional Food Retailers in Asia: Wet Market's Continued Dominance in Hongkong”, Journal of Macromarketing, vol. 19, no. 2, pp. 126-139.

Hernandez, T. (2003), "The Impact of Big Box Internationalization on A National Market: A Case Study of Home Depot Inc, in Canada”, International Review of Retail, Distribution, and Consumer Research, vol. 13, no. 1, pp. 77-98. 
Indonesian Observer, 22 January 1999

Kementerian Perdagangan Republik Indonesia. (2010), "Pasar Tradisional \& Modern Bersinergi Membangun Bangsa”, Penerbit Semesta Media.

Louviere, J, and Garth, G. (1987), “ Decomposing the Determinants of Retail Facility Choice Using the Method of Hierarchical Information Integration: a Supermarket Illustration”, Journal of Retailing, vol. 63, no. 1, pp. 25-48.

Mitchell, V.W. and Kiral, R.H. (1998), "Primary and Secondary Store-Loyal Customer Perceptions of Grocery Retailers”, British Food Journal, vol. 100, no. 7, pp. 312-319.

Moreno, J.A. (2001), "Interurban Shopping, New Town Planning and Local Development in Madrid Metropolitan Area: Case Study”, Journal of Retailing and Consumer Services, vol. 8, pp. 291-298.

Peterson, M. and McGee, J.E. (2000), " Survivors of "W-Day: An Assessment of the Impact of Wal-Mart's Invasion of Small Town Retailing Communities", International Journal of Retail \& Distribution Management, vol. 28, no. 4/5, pp. 170-180.

Seiders, K. And Tiggert, D.J. (2000), “ The Impact of Supercenters on Traditional Food Retailers in Four Markets”, International Journal of Retail \& Distribution Management, vol. 28, no. 4/5, pp. 181-193.

Sensus Penduduk. (2010), "Hasil Sensus Penduduk 2010: Provinsi Jawa Barat", Badan Pusat Statistik.

Setala, A.V. (2000), "Economies of Scale in Grocery Retailing in Finland”, Journal of Retailing and Consumer Services, vol. 7, pp. 207-213.

Shamsudin, D.M. and Selamat, S.J. (2005), "Changing Retail Food Sector in Malaysia”, Presented at Pacific Food System Outlook (FPSO) $9^{\text {th }}$ Annual Forecasters Meeting in Kunming, China.

Singh, V.P.P., Hanse, K.Y. and Blattberg, R.C. (2004), “Impact of Wal-Mart Supercenter on a Traditional Supermarket: An Empirical Investigation”, Working Paper Carnegie Mellon University.

Sinha, K.P. and Banerjee, A. (2004), "Store Choice Behaviour in an Evolving Market”, International Journal of Retail and Distribution Management, vol. 32, no. 10, pp. 482-494.

Stone, K.E. (1995), “Competing with the retail giants”, John Wiley \& Sons, Inc.

Sunanto, S., et al. (2010). "A Study of Modern Market Impact on Consumer Shopping Behavior and Traditional Market in West Java, Indonesia”, Proceedings of the $3^{r d}$ Asia Pacific Marketing Conference, Sarawak, Malaysia.

Sunanto, S. and Tuninga, R.S.J. (2008), "Hypermarkets and Their Impacts on Retail Structure: the Case of Indonesia”, In E. Kaynak and T. Harcar eds., The International Management Development Research Yearbook XVII, pp. 136-142. 
Sunanto, S., \& Tuninga, R.S.J. (2009). "Hypermarkets and Consumers Shopping Behavior: the Case of Carrefour in Indonesia”. In E. Kaynak and T. Harcar eds., International Management Development Research Yearbook, Management Challenges in an Environment of Increasing Regional and Global Concerns, volume XVIII, pp. 540547.

Suryadarma, D., Poesoro, A. and Budiyati, S. (2007). "Impact of Supermarkets on Traditional Markets and Retailers in Indonesia's Urban Centers." SMERU Research Report.

The Nielsen Company (2007), “2007 Retail and Shopper Trends.

The World Bank (2007), "Horticultural Producers and Supermarket Development in Indonesia”, Report no. 38543-ID.

Uusitalo, O. (2001), “Consumer Perceptions of Grocery Retail Formats and Brands”, International Journal of Retail and Distribution Management, vol. 29, no. 5, pp. 214225.

Vance, S.S. and Scott, R. (1994). “Wal-Mart: A History of Sam Walton's Phenomenon”, Twayne Publishers, New York, NY. 